\title{
Article
}

https://doi.org/10.11646/phytotaxa.321.3.6

\section{Aulostemon (Asparagaceae, Scilloideae), a new genus from South Africa}

\author{
MARIO MARTÍNEZ-AZORÍN ${ }^{1 *}$, MANUEL B. CRESPO ${ }^{1}$, MICHAEL PINTER ${ }^{2} \&$ WOLFGANG WETSCHNIG $^{2}$ \\ ${ }^{\prime} d C A R N$ (Depto. Ciencias Ambientales y Recursos Naturales) y CIBIO (Instituto Universitario de la Biodiversidad), Universidad de \\ Alicante, P. O. Box 99,E-03080 Alicante,Spain; e-mail: mmartinez@ua.es \\ ${ }^{2}$ Institute of Plant Science, NAWI Graz, Karl-Franzens University Graz, Holteigasse 6, A-8010 Graz, Austria. \\ "author for correspondence
}

\begin{abstract}
As part of a taxonomic revision of Hyacinthaceae subfamily Urgineoideae (Asparagaceae tribe Urgineeae) based on morphological and genetic data covering numerous samples from its whole range of distribution, we here describe a new genus from south-eastern South Africa. Aulostemon includes Drimia mzimvubuensis, a species recently placed in Sagittanthera. However, distinct morphological character states, especially regarding connation of stamen filaments to form a distinct tube that surrounds the gynoecium, the free anthers, the lack of bracteoles and its isolated phylogenetic position within subfamily Urgineoideae, support the description of the new genus.
\end{abstract}

Key words: Hyacinthaceae, distribution, ecology, Urgineoideae, taxonomy

\section{Introduction}

Hyacinthaceae includes between 700-1000 species of bulbous plants mostly occurring in Africa, Europe and Asia, with a single genus, Oziroë Rafinesque (1837: 53), present in South America (Speta 1998a, b, APG 2003). Four monophyletic subfamilies are accepted in Hyacinthaceae: Hyacinthoideae, Ornithogaloideae, Oziroëoideae and Urgineoideae (Speta 1998b, Pfosser \& Speta 1999, Manning et al. 2004, Martínez-Azorín et al. 2011), a treatment that we favour here. Alternatively, Hyacinthaceae is treated as Asparagaceae subfamily Scilloideae, and consequently the former subfamilies are reduced to the tribes Hyacintheae, Ornithogaleae, Oziroëeae and Urgineeae (APG 2009, 2016, Chase et al. 2009).

In recent decades, the generic circumscriptions of subfamily Urgineoideae have been especially controversial (Martínez-Azorín et al. 2013a, 2013b, 2016, Crouch \& Martínez-Azorín 2015). On the one hand, Manning et al. (2004) presented an extremely broad treatment, where only two genera were recognised for the whole subfamily: Bowiea Harvey ex Hooker (1867: t. 5619) and Drimia Jacquin (1797: 38), the latter including in synonymy several traditionally accepted genera which are easily identified by distinct syndromes of morphological characters, such as Litanthus Harvey (1844: 314), Rhadamanthus Salisbury (1866: 37), Rhodocodon Baker (1880: 280), Schizobasis Baker (1873: 105), Tenicroa Rafinesque (1837: 52), Thuranthos Wright (1916: 233), and Urginea Steinheil (1834: $321)$.

On the other hand, Speta (1998a, b, 2001) and Pfosser \& Speta (2001) favoured a more analytic approach, in which about 20 different genera were accepted. However, several of these genera have proved to be para- or polyphyletic (Pfosser \& Speta 2001, 2004, Manning et al. 2004, Pfosser et al. 2012). Speta (1998a) himself commented that 'the definition of genera in this subfamily is often unsatisfactory'. A similar scenario is found in the sister subfamily Ornithogaloideae, where contrasting taxonomic treatments were recently proposed based on different approaches (Speta 1998a, Manning et al. 2004, 2009, Martínez-Azorín et al. 2011). However, as shown by Martínez-Azorín et al. (2011), when sufficient plastid and nuclear DNA regions are included in the phylogenetic analyses, consistent morphological elements are fully congruent with clades, and these can be accepted at the generic rank. A similar study in Urgineoideae is ongoing that supports the recognition of a multigeneric treatment in the subfamily (M. MartínezAzorín and collaborators, in preparation). 
Van Jaarsveld \& Van Wyk (2005) described two new species of Drimia -D. cremnophila Van Jaarsv. in Van Jaarsveld \& Van Wyk (2005: 81) and D. mzimvubuensis Van Jaarsv. in Van Jaarsveld \& Van Wyk (2005: 83)- from the eastern regions of the Eastern Cape Province of South Africa with similar flower morphology and a distinct androecium morphology. Martínez-Azorín et al. (2013b) described the genus Sagittanthera Martínez-Azorín et al. (2013b: 46) to include two species, S. cyanelloides (Baker 1897: 444) Martínez-Azorín et al. (2013b: 48), the generitype in which D. cremnophila is accepted as a synonym, and S. mzimvubuensis (Van Jaarsv. in Van Jaarsveld \& Van Wyk 2005: 83) Martínez-Azorín et al. (2013b: 51).

Our recent studies on living material evidenced clear morphological and genetic differences among the two species of Sagittanthera. Therefore, following the same morphological and molecular criteria adopted in other subfamilies for generic circumscription (Martínez-Azorín et al. 2011) we here describe a new genus, Aulostemon, to include $S$. mzimvubuensis.

\section{Materials and methods}

Detailed morphological studies were undertaken on cultivated specimens following the terminology used for species of Hyacinthaceae in Martínez-Azorín et al. (2007, 2009). Seed sizes are expressed as L-H-W, meaning Length-HeightWidth. Herbarium specimens from the herbaria ABH, B, BLFU, BM, BOL, E, G, GZU, GRA, HAL, K, L, LINN, M, MO, NBG, NU, NY, P, PRE, S, TCD, UPS, WU, Z, ZSS and ZT (acronyms according to Thiers 2017) were studied. Authors of the cited taxa follow IPNI (2017). Orthography of geographical names and grid-number system follows Leistner \& Morris (1976).

\section{Description of the new genus}

\section{Aulostemon Mart.-Azorín, M.B.Crespo, M.Pinter \& Wetschnig gen. nov. (Fig. 1)}

Similar to Sagittanthera, but differing by the connation of the filaments of the stamens that are as long as or slightly longer than the anthers and form a distinct tube that surrounds the gynoecium (not much shorter than the anthers and free in the former); the free anthers (not connate at least along the distal half); the adaxial side of tepals exhibiting basal green maculae that connect to form a basal green ring (not completely white); and the absence of bracteoles.

Typus generis:-Aulostemon mzimvubuensis (Van Jaarsv.) Mart.-Azorín, M.B.Crespo, M.Pinter \& Wetschnig comb. nov. (holotype).

Basionym:-Drimia mzimvubuensis Van Jaarsv. in Van Jaarsveld \& Van Wyk (2005: 83) $\equiv$ Sagittanthera mzimvubuensis (Van Jaarsv.) Martínez-Azorín et al. (2013b: 51). Type:-SOUTH AFRICA. Eastern Cape Province. Port St. Johns (3129CB), lower Mzimvubu River, south facing shale cliffs near Lutengela, Van Jaarsveld, Xaba, Harrower \& Zwide 58 (PRE! holotype)

Bulbous geophyte. Bulb partially epigeal, with thickened, fleshy, semitranslucent, loose, rounded and club-shape scales, with short, flattened stalks, easily proliferating when detached, not producing threadlike structures when broken. Roots thickened and branched. Leaves 1-4 per bulb, linear, up to $50 \mathrm{~cm}$ long, 2-3 $\mathrm{mm}$ in diameter, leathery, dark green, subterete, slightly channelled on the adaxial side, finely striate with minute hairs. Inflorescence long racemose, the peduncle 25-40 cm long, the raceme long and lax, up to $20 \mathrm{~cm}$ long, with 20-50 nodding flowers, pedicels 14-20 $\mathrm{mm}$ long; the peduncle and pedicels long persistent and photosynthetic after seeds dispersal lasting from flowering time in spring to autumn. Bracts lanceolate, acute, 3-5 mm long, the lowermost with a long basal spur up to $8-9 \mathrm{~mm}$ long; bracteoles absent. Flowers pentacyclic, trimerous, stellate, nodding, opening in the afternoon. Tepals 6, biseriate, free from the base, outer tepals lanceolate, $10-11 \times 2.5-2.8 \mathrm{~mm}$, inner tepals oblong-lanceolate, 9-10 $\times 3-3.5 \mathrm{~mm}$; adaxial side of tepals white with a green macula at the base that connect to form a green basal perigone ring; abaxial side of tepals white with a narrow central and longitudinal green band, the perigone also showing a green basal ring. Stamens 6, filaments flattened and connate along most of their length to form a distinct erect tube of ca. $3.5 \mathrm{~mm}$ long around the gynoecium, ending in short triangular lobes of ca. $1 \mathrm{~mm}$ long that bear free sagittate anthers of ca. $3 \mathrm{~mm}$ long and $0.8 \mathrm{~mm}$ wide at the base, dehiscing by minute apical pores and connivent to the style. Ovary ovoid, trigonous, ca. $2.8 \times 1.8 \mathrm{~mm}$, green. Style narrow, erect, ca. $4.5 \mathrm{~mm}$ long, straight, mostly included in the filaments tube and the connivent anthers, elongating to overtop the anthers after dehiscence of the latter. Stigma small and indistinctly trigonous. Capsule triloculate, loculicide, 7-10 $\times 5.4-7.5 \mathrm{~mm}$, valves splitting to the base. Seeds numerous, flattened, suboblong, L-H-W 5.3-5.6 × 2.2-2.5 × 1.2-1.4 mm, black, with sinuous anticlinal testa cell walls (Figs. 1-2). 


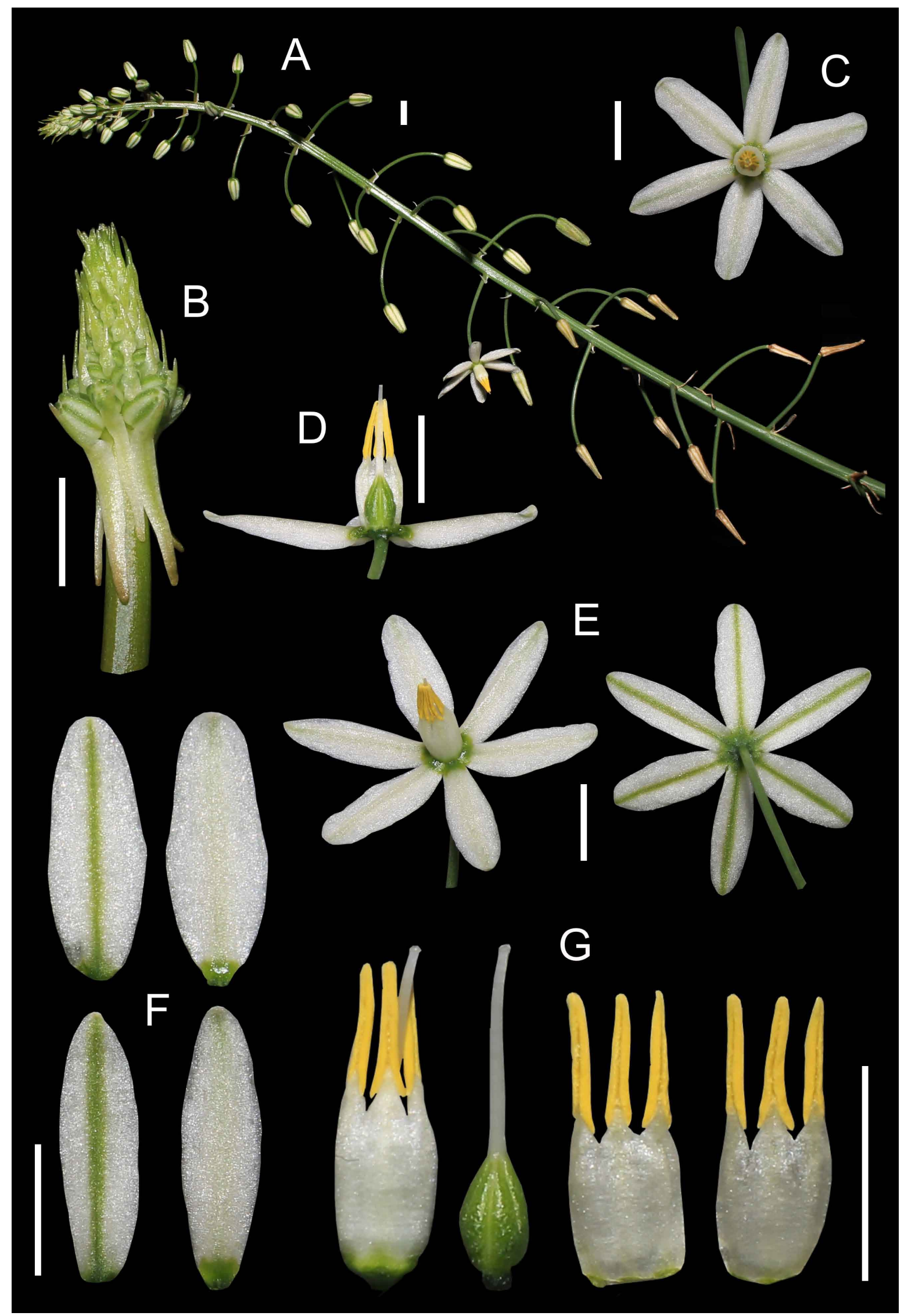

FIGURE 1. Aulostemon mzimvubuensis (Van Jaarsv.) Mart.-Azorín et al. in cultivation from the type locality, lower Mzimvubu River, near Lutengela, Eastern Cape Province of South Africa on 28 May 2014. A. Inflorescence; B. Young inflorescence showing bracts and long spurs; C. Flower, apical view; D. Flower with dissected androecium, lateral view; E. Flowers, adaxial (left) and abaxial (right) sides; F. Tepals, inners above and outers below, abaxial (left) and adaxial (right) sides; G. Androecium and gynoecium, dissected androecium on the right side, lateral views. Scale bars: $5 \mathrm{~mm}$. 

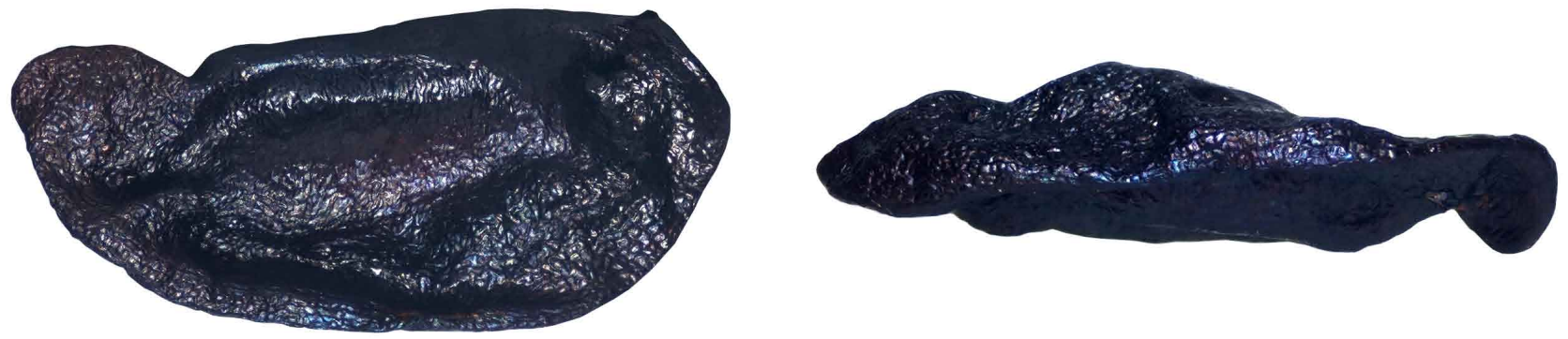

FIGURE 2. Seed of Aulostemon mzimvubuensis (Van Jaarsv.) Mart.-Azorín et al. in cultivation from the type locality, lower Mzimvubu River, near Lutengela, Eastern Cape Province of South Africa. Scale bar: $1 \mathrm{~mm}$.

Etymology:-Aulostemon (Aulos, Greek name $=$ tube, flute; -stemon, Greek = stamens). Named after its characteristic flowers, which show the filaments of stamens connate in a long tube.

Ecology and biogeography:- Rocky grasslands and crevices of vertical shale cliffs, usually south-facing, in thicket vegetation patches, associated with the Eastern Valley Bushveld and Bhisho Thornveld (Mucina \& Rutherford 2006), in subtropical region characterised by summer rainfall and few rains in winter (total yearly precipitation ca. $500-1000 \mathrm{~mm}$ ), and infrequent occurrence of frost.

Distribution:-Eastern parts of the Eastern Cape Province of South Africa, only known from NW of Port St. Johns along the Mzimvubu (uMzimvubu) River gorge.

Taxonomic and phylogenetic notes:-Martínez-Azorín et al. (2013b) described Sagittanthera to include S. cyanelloides and S. mzimvubuensis based on the unique syndrome of morphological characters and the general appearance of their flowers, especially regarding the androecium morphology that is linked to buzz pollination, and similar biogeography. At the time of the description of Sagittanthera, these authors studied living material in cultivation of S. cyanelloides, from which the buzz pollination experiments were performed, but no living material was available of S. mzimvubuensis. We were recently able to study living plants from the type locality of this latter species in cultivation (Fig. 1). This study evidences important morphological differences between the two species of Sagittanthera regarding characters that have been used in other subfamilies of Hyacinthaceae to segregate genera, such as connation of filaments and anthers, colour of tepals or presence of bracteoles (Table 1). Sagittanthera was described as having connate anthers (Martínez-Azorín et al. 2013b). However, the study of fresh material of S. mzimvubuensis revealed that the anthers in this latter species are free but connivent to the style (Fig. 1D, G), a character overlooked when studying photographs and herbarium material by Martínez-Azorín et al. (2013b). This renders the connation of the anthers along their distal half as a unique morphological character of $S$. cyanelloides in the whole family Hyacinthaceae, making recognition of Sagittanthera in a narrow sense very easy. Another interesting difference between the two Sagittanthera species is the presence of green basal maculae on the adaxial side of tepals in S. mzimvubuensis that form a green ring at the base of the perigone (Fig. 1). This is also present on the abaxial side of perigone in a lower degree, whilst the adaxial side of tepals in S. cyanelloides is white (sometimes the darker longitudinal dorsal band of tepals is somewhat visible). The presence of green basal maculae of tepals has been used to recognize the recently described genus Mucinaea M.Pinter, Mart.-Azorín, U.Müll.-Doblies, D.Müll.-Doblies, Pfosser \& Wetschnig in Pinter et al. (2013: 296), that is easily distinguishable by its purplish-pink tepals bearing a double-eyed green floral marking at their base, surrounded by a white margin, unique within Hyacinthaceae (Pinter et al. 2013). The presence of green maculae in S. mzimvubuensis also supports its independence from Sagittanthera in a narrow sense, being also unique within subfamily Urgineoideae, although the green markings in S. mzimvubuensis are different from those in Mucinaea. The presence of bracteoles has also been described as a general character of Sagittanthera (Martínez-Azorín et al. 2013b). However, S. mzimvubuensis lacks bracteoles, therefore differing from the type species in a character used for generic circumscription in Hyacinthaceae (Speta 1998a, 1998b, 2001, Martínez-Azorín et al. 2011). Moreover, filaments of stamens in both species of Sagittanthera are very different. Whilst S. cyanelloides presents free filaments that are much shorter than the connate anthers, S. mzimvubuensis exhibits a long tube formed by the connation of the filaments that surrounds the gynoecium, supporting free but connivent anthers. Connation of filaments was the base to recognize genera in other subfamilies, such as Neopatersonia Schönland (1912: 251) (Martínez-Azorín et al. 2011). It is therefore remarkable, that $S$. mzimvubuensis is unique within subfamily Urgineoideae in having connate filaments allowing easy identification and supporting the description of a new monotypic genus. Other differences in vegetative characters 
between the two species of Sagittanthera regard the formation of threads in the bulb scales of S. cyanelloides when broken (not produced in S. mzimvubuensis), the broad, flattened and distinctly keeled leaves of $S$. cyanelloides (narrower and subterete in S. mzimvubuensis), and the long persistent and photosynthetic stem and pedicels of the inflorescence after seeds release in S. mzimvubuensis (not soon withering after flowering in S. cyanelloides). These character states also evidence the morphological differences between both species. Our phylogenetic studies based on three plastid regions (ycf, matK and trnL-trnF) and a nuclear one (Agt1) include more than 300 samples of Urgineoideae covering its whole distribution and most of the recognized species (M. Martínez-Azorín and collaborators, in preparation). Our results (not shown) recover S. cyanelloides and S. mzimvubuensis in isolated positions within the subfamily and placed far from each other (M. Martínez-Azorín and collaborators, in preparation). Whilst $S$. cyanelloides is located as sister to Thuranthos and Urginavia Speta (1998b: 86), S. mzimvubuensis forms a different branch sister to Rhadamanthopsis (Obermeyer 1980: 137) Speta (1998b: 74). According to the data shown above, remarkable morphological and genetic differences existing between $S$. cyanelloides and $S$. mzimvubuensis support their segregation as two distinct genera, and therefore, the description of the new genus Aulostemon to accommodate the former S. mzimvubuensis. Inclusion of Sagittanthera cyanelloides in a single genus together with Thuranthos and Urginavia would be highly disruptive, as both latter genera show very different flower morphology and free anthers. On the other hand, although Aulostemon (A. mzimvubuensis) is sister to Rhadamanthopsis (Obermeyer 1980: 137) Speta (1998b: 74), the latter genus has campanulate nodding flowers with connate tepals, and free filaments (in part adnate to the perigone tube) and anthers, what does not allow inclusion of $A$. mzimvubuensis.

TABLE 1. Main differences between Aulostemon and Sagittanthera.

\begin{tabular}{|c|c|c|}
\hline & Aulostemon & Sagittanthera \\
\hline Bulb scales & $\begin{array}{l}\text { semitranslucent, with no threadlike structures } \\
\text { when broken }\end{array}$ & $\begin{array}{l}\text { fibrous with dense slimy threadlike structures } \\
\text { when broken }\end{array}$ \\
\hline Leaves & subterete & flat with a broad abaxial keel \\
\hline Bracteoles & absent & present \\
\hline Inflorescence & $\begin{array}{l}\text { long persistent and photosynthetic after seeds } \\
\text { release }\end{array}$ & soon withering after flowering \\
\hline Adaxial side tepals colour & $\begin{array}{l}\text { white with a green macula at base forming a green } \\
\text { basal ring }\end{array}$ & white \\
\hline Filaments & $\begin{array}{l}\text { connate in a long tube that surrounds the } \\
\text { gynoecium, as long as or longer that the anthers }\end{array}$ & free, much shorter than the anthers \\
\hline Anthers & free but connivent to the style & connate at least along the distal half \\
\hline
\end{tabular}

\section{Acknowledgements}

This work was partly supported by Fundación Ramón Areces (Spain), and H2020 Research and Innovation StaffExchange Programme of the European Commission, project 645636: 'Insect-plant relationships: insights into biodiversity and new applications' (FlyHigh). Ernst van Jaarsveld is thanked for providing living material of Aulostemon mzimvubuensis from the type locality. Rhodes University provided working facilities from October 2009 and November 2011. We thank the curators of the herbaria, who provided access to the specimens examined. Two anonymous reviewers and Lorenzo Peruzzi made interesting comments on the manuscript.

\section{References}

Angiosperm Phylogeny Group (2003) An update of the Angiosperm Phylogeny Group classification for the orders and families of flowering plants: APG II. Botanical Journal of the Linnean Society 141: 399-436. https://doi.org/10.1046/j.1095-8339.2003.t01-1-00158.x

Angiosperm Phylogeny Group (2009) An update of the Angiosperm Phylogeny Group Classification for the orders and families of flowering plants: APG III. Botanical Journal of the Linnean Society 161: 105-121.

https://doi.org/10.1111/j.1095-8339.2009.00996.x

Angiosperm Phylogeny Group (2016) An update of the Angiosperm Phylogeny Group Classification for the orders and families of flowering plants: APG IV. Botanical Journal of the Linnean Society 181: 1-20. 
https://doi.org/10.1111/boj.12385

Baker, J.G. (1873) On Schizobasis, a new genus of Liliaceae from Cape Colony. Journal of Botany, British and Foreign 11: 105.

Baker, J.G. (1880) Notes on a collection of flowering plants made by L. Kitching, Esq., in Madagascar in 1979. Journal of the Linnean Society, Botany 18: 264-281.

https://doi.org/10.1111/j.1095-8339.1881.tb01257.x

Baker, J.G. (1897) Liliaceae. In: Thiselton-Dyer, W.T. (Ed.) Flora Capensis 6. Reeve and Co., London, pp. 253-525.

Chase, M.W., Reveal, J.L. \& Fay, M.F. (2009) A subfamilial classification for the expanded asparagalean families, Amaryllidaceae, Asparagaceae and Xanthorrhoeaceae. Botanical Journal of the Linnean Society 161: 132-136.

https://doi.org/10.1111/j.1095-8339.2009.00999.x

Crouch, N.R. \& Martínez-Azorín, M. (2015) Drimia edwardsii (Asparagaceae, Scilloideae), a new urgineoid species from the Mkhomazi River Valley of eastern South Africa. Phytotaxa 195: 135-144.

https://doi.org/10.11646/phytotaxa.195.2.2

Harvey, W.H. (1844) Litanthus, a new genus of Asphodeleae from South Africa. The London Journal of Botany 3: 314-315.

Hooker f., J.D. (1867) Bowiea volubilis. Curtis's Botanical Magazine Ser. 3 23: t. 5619.

IPNI. (2017) The international plant names index. Available from http://www.ipni.org (accessed June 2017).

Jacquin, N.J. (1797) Observationes botanicae DXIX-DCLXXI. Collectaneorum Supplementum 5. Officina Wappleriana, Vindobonae [Wien], $220 \mathrm{pp}$.

Leistner, O.A. \& Morris, J.W. (1976) Southern African place names. Annals of the Cape Provincial Museum 12: 1-565.

Manning, J.C., Goldblatt, P. \& Fay, M.F. (2004) A revised generic synopsis of Hyacinthaceae in Sub-Saharan Africa, based on molecular evidence, including new combinations and the new tribe Pseudoprospereae. Edinburgh Journal of Botany 60: 533-568.

Manning, J.C., Forest, F., Devey, D.S., Fay, M.F. \& Goldblatt, P. (2009) A molecular phylogeny and a revised classification of Ornithogaloideae (Hyacinthaceae) based on an analysis of four plastid DNA regions. Taxon 58: 77-107.

Martínez-Azorín, M., Crespo, M.B. \& Juan, A. (2007) Taxonomic revision of Ornithogalum subg. Cathissa (Salisb.) Baker (Hyacinthaceae). Anales del Jardín Botánico de Madrid 64: 7-25.

Martínez-Azorín, M., Crespo, M.B. \& Juan, A. (2009) Taxonomic revision of Ornithogalum subg. Beryllis (Hyacinthaceae) in the Iberian Peninsula and the Balearic Islands. Belgian Journal of Botany 142: 140-162.

Martínez-Azorín, M., Crespo, M.B., Juan, A. \& Fay, M.F. (2011) Molecular phylogenetics of subfamily Ornithogaloideae (Hyacinthaceae) based on nuclear and plastid DNA regions, including a new taxonomic arrangement. Annals of Botany 107: 1-37. https://doi.org/10.1093/aob/mcq207

Martínez-Azorín, M., Crespo, M.B. \& Dold, A.P. (2013a) Drimia cochlearis (Hyacinthaceae), a new species from South Africa. Systematic Botany 38: 332-338.

Martínez-Azorín, M., Crespo, M.B., Dold, A.P., Wetschnig, W., Pinter, W., Pfosser, M., \& van Jaarsveld, E. (2013b) Sagittanthera (Hyacinthaceae, Urgineoideae), a new buzz pollinated genus from the Eastern Cape Province of South Africa. Phytotaxa 98 (2): 43-54.

Martínez-Azorín, M., Dold A.P. \& Crespo, M.B. (2016) Drimia trichophylla (Hyacinthaceae, Urgineoideae), a new species from the Eastern Cape Province, South Africa. Systematic Botany 41: 944-949.

Mucina, L. \& Rutherford, M.C. (Eds.) (2006) The vegetation of South Africa, Lesotho and Swaziland. South African National Biodiversity Institute, Pretoria, 807 pp.

Obermeyer, A.A. (1980) A new subgenus Rhadamanthopsis and two new species of Rhadamanthus. Bothalia 13: 137-139.

Pinter, M., Crespo, M.B., Ilg, I., Luidold, A.K., Martínez-Azorín, M., Müller-Doblies, U., Müller-Doblies, D., Pfosser, M. \& Wetschnig, W. (2013) Mucinaea (Hyacinthaceae-Urgineoideae), a remarkable new genus from Namaqualand (Northern Cape Province, South Africa). Phyton 53: 289-304.

Pfosser, M. \& Speta, F. (1999) Phylogenetics of Hyacinthaceae based on plastid DNA sequences. Annals of the Missouri Botanical Garden 86: 852-875.

https://doi.org/10.2307/2666172

Pfosser, M. \& Speta, F. (2001) Bufadienolides and DNA sequences: on lumping and smashing of subfamily Urgineoideae (Hyacinthaceae). Stapfia 75: 177-250.

Pfosser, M. \& Speta, F. (2004) From Scilla to Charybdis - is our voyage safer now? Plant Systematics and Evolution 246: 245 -263.

Pfosser, M., Knirsch, W., Pinter, M., Ali, S., Dutta, S. \& Wetschnig, W. (2012) Phylogenetic relationships of Malagasy Hyacinthaceae. Plant Ecology and Evolution 145: 65-72.

https://doi.org/10.5091/plecevo.2012.590

Rafinesque, C.S. (1837) Flora Telluriana 3. H. Probasco, Philadelphia, PA, 100 pp.

Salisbury, R.A. (1866) The genera of plants: a fragment containing part of Liriogamae. John van Voorst, London, 143 pp.

Schönland, S. (1912) Neopatersonia, a new genus of Liliaceae. Record of the Albany Museum 2: 251-253. 
Speta, F. (1998a) Hyacinthaceae. In: Kubitzki, K. (Ed.) The families and genera of vascular plants 3. Springer, Berlin, pp. 261-285.

Speta, F. (1998b) Systematische Analyse der Gattung Scilla L. s.l. (Hyacinthaceae). Phyton (Horn) 38: 1-141.

Speta, F. (2001) Die echte und die falsche Meerzwiebel: Charybdis Speta und Stellarioides Medicus (Hyacinthaceae), mit Neubeschreibungen und Neukombinationen im Anhang. Stapfia 75: 139-176.

Steinheil, A. (1834) Note sur le genre Urginea nouvellement formé dans la famille des Liliacées. Annales des Sciences Naturelles, Botanique sér. 2, 1: 321-332.

Thiers, B. (2017) Index Herbariorum: A global directory of public herbaria and associated staff. New York Botanical Garden's Virtual Herbarium. Available form: http://sweetgum.nybg.org/ih/ (continuously updated; accessed June 2017).

Van Jaarsveld, E.J. \& Van Wyk, A.E. (2005) Two new succulent cliff-dwelling species of Drimia (Hyacinthaceae) from the Eastern Cape, South Africa. Aloe 42: 81-83.

Wright, C.H. (1916) Diagnoses africanae: LXIX. Bulletin of Miscellaneous Information, Royal Gardens, Kew 1916: $229-235$. https://doi.org/10.2307/4114331 